\title{
Editorial
}

\section{Legal requirements and responsibilities of the audit committee under Sarbanes-Oxley}

The regulation of audit committees under Sarbanes-Oxley represents a foray of the federal government into corporate governance, an activity which until now has been largely a matter of state regulation. While officers have been within the purview of the securities laws, directors have been subject to federal securities regulation only in connection with their own sale or purchase of securities (except in certain instances, particularly in connection with registration statements) or as the result of material misstatements of information. Directors may have an affirmative duty to disclose material information under certain circumstances, and recklessness in the conduct of their duties may lead to liability under the Private Securities Litigation Reform Act (PSLRA). But changing the norms of corporate governance may prove even more important than the new liability environment to which it gives rise.

Under Sarbanes-Oxley section 301, US listed companies must have audit committees which are independent and include at least one financial expert or disclose why not. In order to meet the Securities and Exchange Commission (SEC) definition of independence, a director must not be a greater than 10 per cent shareholder, nor receive any fees - including consulting, or advisory, legal or accounting fees - from the company or its subsidiaries. No compensation can be made to the immediate family of the audit committee member or to an entity in which the audit committee member is a partner, member or officer occupying a position comparable to an officer or director; and must not be an affiliate of such a company (a 10 per cent shareholder). The New York Stock Exchange (NYSE) proposed even more stringent rules which require a five-year cooling-off period for amounts in excess of US\$100,000 in the event that an audit committee member or immediate family member has been employed in a professional capacity by the firm's internal or external auditor, or if the company of which the audit committee member is an executive officer is a company which accounts for more than 2 per cent of the gross revenues of the listed company. NASDAQ proposed rules define independence as excluding anyone who has, for any of the previous three fiscal years, received a payment in excess of US\$60,000 except as a member of the board of directors, excluding employee benefits or investments if the proposed director or family member was an executive officer.

Under Sarbanes-Oxley section 407, companies must disclose whether the audit committee has among its members at least one financial expert, and if not, why not. A financial expert under the final SEC rules is a person who has:

- an understanding of Generally Accepted Accounting Principles (GAAP);

- the ability to assess the general application of GAAP in connection with the accounting for estimates, accruals and reserves;

- experience of either preparing, auditing or analysing financial statements that present a breadth and level of complexity of accounting issues that are reasonably 
comparable to those that the issuer's financial statements can reasonably be expected to reach or actively supervising individuals engaged in these activities.

These attributes must have been acquired through:

- education or experience as a principal financial officer, comptroller, public accountant or auditor or person performing similar functions;

- actively supervising such a person;

- experience overseeing or assessing the performance of companies or public accountants with respect to the preparation, auditing or evaluation of financial statements;

- other relevant experience.

The 'safe harbour' provides that this designation will not impose any greater duties or liabilities than would otherwise affect the member of the audit committee, nor will it affect the duties or liabilities of other members of the board. This definition safely incorporates former Arthur Anderson partners and chief executive officers (CEOs) as well as many financial analysts and investment bankers (explicitly named in the SEC release) with no formal training in accounting, but excludes accounting professors who run training programmes for auditors. The independence and financial expert rules must not be expected to serve as a quick fix for the problems of corporate governance relating to financial statements. We should recall that the archetype of dysfunctional audit committees, Enron's, included Robert Jaedecke, who was Dean of Stanford Business School, and the only limitations on independence involved Enron donations to charitable institutions where Board members were employees.

The listing of securities by a foreign private issuer exempts foreign private issuers if:

- the foreign private issuer has a statutory board of auditors pursuant to home-country laws or listing requirements;

- the board of auditors is separate from the board of directors or composed of one or more members of the board of directors and one or more members who are not also members of the board of directors;

- has listings or home-country laws which have different standards of independence from issuer or management;

- has no executive member of the issuer on the board of issuers;

- the board of auditors has responsibility for the appointment and retention of auditors, to the extent permissible by law;

- the audit committee requirements relating to retention of advisers and funding and the complaint procedures relating to audits apply to the board of auditors. ${ }^{1}$

Responsibilities of the audit committee include:

- appointment, compensation, retention and oversight of any work done by registered public accounting firms engaged for the purposes of preparing an audit report or any other audit; reviewing or attesting services; and review of non-audit work to determine whether these services are prohibited under Sarbanes-Oxley;

- adopting procedures for the receipt, retention and treatment of complaints regarding accounting and internal control and for confidential anonymous submissions;

- having authority and proper funding for the retention of independent counsel and outside advisers as it deems necessary;

- under section 204 receiving reports from outside auditor on all critical accounting policies and alternative treatment of financial information, within GAAP related to material items discussed with management, including ramifications of the use of alternative treatments and the treatment preferred by the outside auditor 
and all other material written communication.

Additional NYSE rules would require:

- at least annually, obtain and review a report by the independent auditor on the firm's internal controls, which must describe any issues raised by the internal audit or by any inquiry or investigation by a government or professional authority within the last five years and any steps the firm has taken to deal with such issues, and must assess auditors' independence;

- discuss with management and internal auditors the quarterly and annual statements, including the company's disclosure under Management Discussion and Analysis;

- review earnings press releases, financial information and quarterly financial statements, financial information and earnings guidance given to analysts and credit rating agencies;

- discuss policies with respect to risk assessment;

- meet separately or periodically with management, internal auditors and independent auditors;

- review with independent auditors any audit problems;

- set clear hiring policies for employees or former employees of the independent auditors;

- report regularly to the board of directors.

A related provision requires that each listed company have an independent audit function which reports regularly to the audit committee. Additionally, companies must have 'corporate governance guidelines' which address, inter alia, responsibilities of directors and director access to management. A littlenoticed provision requires director orientation and continuing education.

The audit-committee powers with regard to appointment of auditors have recently been exercised by certain companies in such a way that management has only learned of the appointment of the auditor after the fact. Other companies, no doubt, continue to rubber-stamp management choices. But 56 per cent of companies will submit the choice of auditor to a shareholder vote, according to a Deloitte and Touche survey. The survey also indicates a greater involvement by audit committees in reviewing financial statements. At April 2003, 71 per cent of full audit committees reviewed 10Qs before filing, as against 46 per cent at September 2002, and 85 per cent had already established whistleblower procedures. $^{2}$ Companies are thus getting up to speed with the requirements.

None of this indicates how effective audit committees will be in their new-found Sarbanes-Oxley roles. Absent from the discussion has been any thoroughgoing analysis of what kind of accounting violations audit committees should be on the lookout for. Certainly, Sarbanes-Oxley and NYSE detailed rules, if followed to the letter, will provide better control, but even so, they do not imply an active dialogue on accounting policies. Some hint of what audit-committee members must focus on is given by the requirement that audit committee members have an understanding of estimates, accruals and reserves. Does this imply some knowledge of matching income and expenses or estimating contingent liabilities? Does it imply a familiarity with the SEC releases on revenue recognition and the case law of channel stuffing?

In Worldcom, according to an internal report, there is no evidence that the outside auditor was aware of the mischaracterisation, and no degree of vigilance on the part of the audit committee would have revealed that more than US $\$ 9 \mathrm{bn}$ had been capitalised rather than expensed. In Enron, we do not find anything particularly egregious about the waiver of the code of ethics. We do, however, find the audit committee's, and the board's, lack of interest in the underlying 
transactions which they approved to be astonishing. The decision to 'blow out' liabilities should meet with scepticism on the part of any reasonably astute businessman, much less a professor of accounting. Even given the $97 / 3$ rule, the extent of the liabilities to be included in these specialpurpose entities ought to have been a matter of concern.

The Worldcom report highlights that director vigilance by itself will do little to cure financial fraud. But as part of a system of checks and balances, particularly in insisting on the best internal controls as proposed by auditing experts, these new responsibilities might prove effective. The final report of Richard Breedon, the court-appointed Worldcom monitor, issued a series of recommendations to improve corporate governance which goes well beyond the NYSE rules. These recommendations, unanimously approved by Worldcom's board of directors, include separating the offices of chairman and $\mathrm{CEO}$; requiring all directors other than the CEO to be independent; requiring the full board to meet eight times a year; and substantially raising directors' compensation. ${ }^{3}$ These changes will also raise, at least in terms of best practice, the standards expected of audit-committee members.

Under NYSE rules, the audit committee must review the internal audit function. One internal control memo by a Big Four accounting firm suggests certain criteria for analysing internal control through an 'accounts' approach at the consolidated level and lists several factors (other than size of accounts) to be considered, including volume of activity; homogeneity of transactions; the extent to which account balance is subjectively determined; changes in accounts characteristics; and separation by organisational structure or business unit. Components of each account for a sample manufacturing firm include financial statement close; cash receipts and disbursements; sales and accounts receivables; estimated commitments and contingencies; warranty reserve and exposure; plant depreciation and amortisation; obsolete inventory reserves; currency adjustments; purchase and pay for assets; pension liabilities; LIFO calculations etc which include routine, non-routine and estimates. While such detailed checklists are useful, there is no apparent correlation between the number of 'boxes checked' and the accuracy of financial statements. In this regard, the implementation of the detailed rules approach adopted by the NYSE may not enhance audit-committee oversight.

Sarbanes-Oxley, particularly those provisions involving audit-committee responsibility, represents an unprecedented foray by federal regulation into corporate law. Before Sarbanes-Oxley, federal securities law was focused on the acts of officers, and did not usually, except in instances of self-dealing, consider the duties of directors. State law, which has generally found that directors owe a fiduciary duty to the corporation, has zealously guarded the business judgment rule, absent self-dealing (violating the duty of loyalty). According to the Delaware Chancery Court in Smith $v$ Van Gorkham, acts amounting to gross negligence invited judicial review of corporate transactions. ${ }^{4}$ But directors were insulated from much of this additional liability by statutes that allowed shareholders to adopt by-laws to insulate directors from claims arising from breach of the fiduciary duty of care ${ }^{5}$ although misleading disclosure to shareholders in the context of shareholder actions such as proxy fights or merger votes may conceivably give rise to liability. But in May 2003 the Delaware Chancery Court, in a memorandum opinion, allowed a derivative action against Disney, arising out of allegations relating to Michael Ovitz's employment contract, to proceed. ${ }^{6}$ The court noted:

'It is rare when a court imposes liability on directors for a breach of the duty of care, 
and this Court is hesitant to second guess the business judgment of a disinterested and independent board of directors. But the facts alleged in the new complaint do not implicate merely negligent or grossly negligent decision making by corporate directors. Quite the contrary; plaintiff's new complaint alleges that the Disney directors failed to make any business judgment and failed to make any good faith attempt to fulfill their fiduciary duties to Disney and its stockholder. ${ }^{7}$

As Chancellor William Chandler and Vice Chancellor Leo Strine stated in a paper last year, new expectations created by SarbanesOxley may 'generate new types of state corporate law cases' against directors. The authors conjecture:

'One form that these cases may take could involve claims that directors are breaching their fiduciary duties by not complying with the reform... [that state law] ought to embrace the substance of a feature of the Reforms...[or] an allegation that directors breach their fiduciary duties by exposing the corporation (and therefore its stockholders) to an injurious sanction (eg, delisting) that may be imposed if the Reforms are not adhered to.'

This editorial will not go so far as various editorials and corporate lawyers have gone, to suggest that the recent decision involving Disney represents a quantum leap in state corporate law. It is more likely that a paradigm shift in directors' liability will occur - if ever - as the result of failure on the part of an audit committee to disclose or act upon evidence of a material violation of securities law, particularly with reference to financial statements. That federal class actions, rather than state law derivative actions, will become the vehicle for the mainstay of actions against directors indicates the degree to which Sarbanes-Oxley feder- alises corporate law. Until recent financial scandals, few class-action suits under the PSLRA have named outside directors, and those who were named were alleged to be responsible for misstatements. ${ }^{9}$ The wave of corporate scandals has dramatically changed the landscape, as directors in Enron and elsewhere face personal liability in situations in which directors and officers (D\&O) insurers may dispute the policy coverage. In most instances, indemnification by the company will reimburse directors, but directors of insolvent companies may face real personal liability; and $\mathrm{D} \& \mathrm{O}$ insurers are claiming the right of rescission in the event of material restatements. The operative question, in terms of director's liability in federal classaction suits, is what kind of director behaviour rises to the level of recklessness required to show scienter under the PSLRA.

But the enhanced role of audit committees must not be seen in a vacuum. Legal scholars such as Professor John Coffee view the wave of corporate scandals as resulting, in large measure, from the failure of traditional gatekeepers, particularly lawyers and accountants, to perform their professional responsibilities to the corporation with diligence. Sarbanes-Oxley section 307 requires lawyers to report up the line "whenever it would be unreasonable for a reasonable and prudent attorney to fail to conclude that the evidence makes it reasonably likely that a material violation of the securities law has occurred, is likely to occur or is ongoing'; all such violations which involve financial statements, whether or not via a Qualified Legal Compliance committee, chief legal officer or CEO, will eventually make their way to the audit committee. When the Public Company Accounting Oversight Board (PCAOB) has set forth ethical obligations for auditors, there will be instances when auditors will report directly or indirectly to the audit committee. Also, if faced with material evidence of interfering with a whistleblower or an auditor, the audit 
committee must report to the board of directors. In particular, the section 204 review of alternative accounting treatments discussed with management and the auditor's preferred treatment will require the audit committee to take decisions in the event of any conflict between the auditor and management or, even if the audit committee disagrees with management and the auditor. The enhanced responsibilities of the audit committee make it evident that the audit committee will have much more significant knowledge of the financial reporting regime of the company, and with the knowledge comes responsibility and potential exposure to liability. If the board of directors, after a proper investigation, fails to take appropriate action (which would probably include dismissing any officer engaged in violation of the securities law, after an investigation in which the offending officer is given a chance to make an affirmative defence), it will risk exposure to liability. It is unclear whether halfway measures will suffice, or what absent adjudication - the audit committee (with legal advice) will determine to be a material violation of the securities law, or whether the SEC must be informed. If a misleading or fraudulent financial statement or pro forma statement has been issued, the audit committee or the full board, in order to avoid liability, will, in the authors' view, require that the violation be reported to the SEC. In either event, public disclosure would be the safest course of action.

The Sarbanes-Oxley approach to corporate governance is a system of checks and balances, in which, for instance, the audit committee hires and fires the auditors and reviews pro forma disclosures; CFOs and CEOs certify financial statements; lawyers report up the line; and accountants are subject to the ethics requirements of the PCAOB. While directors might face increased liability as an unintentional consequence, the clear intent of the Act is to change the norms of corporate governance rather than to spread liability. The only problem is the medium in which these players act: GAAP. The tortuous logic of accounting standards is bound to continue to cause confusion. GAAP has ambiguous standards relating to 'big bath' restructuring, 'cookie jar' reserves, write-offs in connection with a merger, mismatching of earnings and expenses and voluminous standards for derivatives. The crux of Sarbanes-Oxley is to limit the possibility of false and misleading financial statements; but nebulous and overly detailed accounting rules allow auditors and management to pick from a Chinese menu of options for stating earnings.

Without more clearly defined standards, audit committees will have no means of determining which accounting standards are appropriate and which are misleading or fraudulent. The SEC's release, pursuant to Sarbanes-Oxley, on principles-based accounting, together with the Federal Accounting Standards Board's decision to seek convergence with International Accounting Standards, offers some hope that GAAP standards will eventually become more coherent. In the meantime, audit committees should attempt to work diligently through the tangled web of GAAP standards to ensure that financial statements are as accurate as the current reporting system will permit.

\section{References}

1 The SEC has clarified, for the purpose of the rules, that the non-management supervisory board constitutes the board of directors. The SEC has also issued a 'no conflicts' clarification, such as homecountry rules which prohibit the board of directors from delegating responsibilities to the audit committee or which vest such powers with a Government entity, in which situations the Sarbanes-Oxley designated audit committee should perform such duties to the extent permitted by law.

2 Deloitte and Touche, Audit Committee and Governance Survey, April 2003. 
3 The Breedon Report also calls for an internet site where shareholders can vote on resolutions without approval at the annual meeting and sets a maximum pay package, including options and other remuneration, for the CEO.

4488 A.2d 858 (Del. 1985), in which directors approved the sale of a company in two hours, without seeing the final version of the contract of sale.

5 eg Del. Code Ann. Title 8, 102(b)(7).

6 In re Walt Disney Company Derivative Litigation, Del. Chancery Court, Consolidated C.A. no. 15452 (28th May, 2003).

7 Ibid., at 2. Five other cases have also ruled against outside directors in cases alleging breach of fiduciary duty on procedural grounds: Telxon v Meyerson 802 A.2d 257 (Del. 7th June, 2002); Saito v McKesson $H B O C$, Inc (reversing grant of summary judgment), Saito $v$ McKesson HBOC, Inc 806 A.2d 113 (Del. 11th June, 2002) (reversing decision limiting access to books and records by shareholders); Levco Alternative Fund Ltd v Reader's Digest Association,
Inc 803 A.2d 428 (Del. 13th August, 2002) (reversing denial of motion for preliminary injunction); MM Cos. $v$ Liquid Audio, Inc 813 A.2d 1118 (Del. 7th January, 2003) (reversing final judgment dismissing challenge to board decision to adopt defensive measures that changed the size and composition of the board during a proxy contest); OmniCare, Inc v NCS Healthcare, Inc 818 A.2d 914 (Del. 4th April, 2003) (reversing denial of summary judgment).

8 Chandler, W. and Strine, L. (2002) 'The new federalism of the American corporate governance system: Preliminary reflections of two residents of one small state', University of Pennsylvania Law Review, Research Paper 03-03. http://papers.ssrn. $\mathrm{com} / \mathrm{sol3} /$ papers.cfm?abstractid $=367720$.

9 Thompson, R. and Sale, H. (2003) 'Securities fraud as corporate governance: Reflection upon federalism', Vanderbilt University Law School Law and Economics Working Paper No. 02-27. Outside directors named are often alleged to have been involved in insider trading. 